\title{
Seroprevalence and risk factors associated with ovine toxoplasmosis in Northeast Brazil
}

\author{
Milena M. Clementino Andrade ${ }^{1,2}$, Mariangela Carneiro ${ }^{1}$, Andrea D. Medeiros ${ }^{2}$, Valter Andrade Neto $^{2}$, \\ and Ricardo W.A. Vitor ${ }^{1}{ }^{*}$ \\ 1 Departamento de Parasitologia, Instituto de Ciências Biológicas, UFMG, Belo Horizonte, MG, Brazil \\ 2 Departamento de Microbiologia e Parasitologia, Centro de Biociências, UFRN, Natal, RN, Brazil
}

Received 26 December 2012, Accepted 14 May 2013, Published online 28 May 2013

\begin{abstract}
Serum samples of 930 sheep were tested by ELISA to assess the prevalence of anti-Toxoplasma gondii antibodies and to identify risk factors associated with the presence of toxoplasmosis in two regions of Rio Grande do Norte (Northeast Brazil), with different climatic conditions. The overall estimated prevalence was $22.1 \%$, with $26.3 \%$ and $17.8 \%$ positive sheep in Leste Potiguar and Central Potiguar regions, respectively. Among the positive sheep, $18.1 \%$ had low-avidity IgG antibodies, suggesting the occurrence of recent toxoplasmosis. The risk factors for toxoplasmosis in sheep were: presence of cats (odds ratio $(\mathrm{OR})=1.55$; confidence interval $(\mathrm{CI}) 95 \%=1.11-$ 2.16), age of the animals, with adults presenting a greater chance of infection ( $\mathrm{OR}=2.44$; CI 95\% $=1.58-3.75)$, and the use of running water $(\mathrm{OR}=1.61$; CI $95 \%=1.25-2.09)$, characterizing the existence of transmission by sporulated oocysts of T. gondii in the environment.
\end{abstract}

Key words: Toxoplasma gondii, sheep, ELISA, seroprevalence.

Résumé - Séroprévalence et facteurs de risque associés à la toxoplasmose ovine dans le Nord-Est du Brésil. Des échantillons de sérum de 930 moutons ont été analysés par le test ELISA dans le but d'évaluer la prévalence d'anticorps anti-Toxoplasma gondii et d'identifier les facteurs de risque associés à la présence de toxoplasmose chez les ovins dans deux régions de l'État de Rio Grande do Norte (Nord-Est du Brésil), ayant des conditions climatiques distinctes. La prévalence estimée était de $22.1 \%$, dont $26.3 \%$ et $17.8 \%$ de moutons positifs, respectivement, dans les régions Leste Potiguar et Central Potiguar. Chez les moutons positifs, 18,1\% ont présenté des anticorps IgG de basse-avidité, suggérant des événements récents de toxoplasmose. Les facteurs de risque associés à l'infection étaient : la présence de chats (rapport de cotes 1.55 ; intervalle de confiance $95 \% 1.11-2.16$ ), l'âge des animaux, les adultes ayant une plus grande chance d'infection (rc 2.44 ; ic 95\% 1.58-3.75), et l'utilisation d'eau courante (rc 1.61; ic $95 \% 1.25-2.09$ ), caractérisant ainsi l'existence de transmission par oocystes sporulés de $T$. gondii dans l'environnement.

\section{Introduction}

Toxoplasmosis is a zoonotic disease caused by the intracellular protozoon Toxoplasma gondii, capable of infecting homeothermic animals, including sheep and humans [10]. It is transmitted mainly by food or water contaminated by oocysts disseminated by cats and other felids (definitive hosts), raw or undercooked meat containing tissue cysts, or transplacentally [29]. In Natal city (capital of Rio Grande do Norte State), $66 \%$ of 190 pregnant women presented IgG antibodies to $T$. gondii [2]. In sheep, T. gondii can cause abortions during recent

\footnotetext{
*Corresponding author: ricardovitor@icb.ufmg.br
}

infection, birth defects, and stillbirths [20, 22, 30] resulting in significant economic and reproductive losses, besides public health implications, considering consumption of infected meat, and milk by the population facilitating the zoonotic transmission [22]. In Brazil, seroepidemiological studies on sheep herds in different regions reported an anti- $T$. gondii $\operatorname{IgG}$ frequency varying from $7.0 \%$ in Paraná to $59 \%$ in Fernando de Noronha [9]. Additionally, T. gondii IgG avidity can be a good marker of recent infection in sheep [5,7], without the need for several reagents for the determination of recent toxoplasmosis. Given the global importance of toxoplasmosis in sheep and the few data available on its prevalence in the state of Rio Grande do 
Norte, limited to only two counties [7, 27], the objective of this study was to determine the seroprevalence of $T$. gondii in sheep from two regions with distinct climatic conditions, as well as to assess the possible risk factors associated with the infection caused by this etiological agent and to detect early toxoplasmosis by research of anti- $T$. gondii IgG avidity.

\section{Material and methods}

\section{Study area}

The state of Rio Grande do Norte, in northeastern Brazil, is situated between the parallels of $4^{\circ} 49^{\prime} 53^{\prime \prime}$ and $6^{\circ} 58^{\prime} 57^{\prime \prime}$ south latitude, and meridians $35^{\circ} 58^{\prime} 03^{\prime \prime}$ and $38^{\circ} 36^{\prime} 12^{\prime \prime}$ west of Greenwich. The annual median temperature of the state is around $25.5{ }^{\circ} \mathrm{C}$, with maximum and minimum of $31.3{ }^{\circ} \mathrm{C}$ and $21.1{ }^{\circ} \mathrm{C}$, respectively, and irregular rainfall. The semiarid climate prevails in $60 \%$ of the state, characterized by low rainfall, around $400-600 \mathrm{~mm}$ per year. The state is divided into four major geographic regions: Agreste Potiguar, Leste Potiguar, Central Potiguar, and Oeste Potiguar. In this study, the animals originate from two regions with distinct climatic characteristics: Leste Potiguar (wet tropical climate) and Central Potiguar (semiarid climate) [14]. In Rio Grande do Norte state, sheep are raised predominantly under a semi-intensive management for meat production.

\section{Animals and serum}

Sample size was determined using the Epi-Info software, version 6.0, based on an assumed prevalence of 29.41\% [7] and was calculated using the following parameters: (1) acceptable error range of 0.05 ; (2) design effect of 2.0 (the samples are not independent, animals were grouped by properties); (3) confidence interval of $95 \%$. The minimum sample size was estimated in 922 sheep (461 per each region).

The survey was conducted from June 2008 to December 2009 and the animals were selected from 25 farms in the state, through a non-probabilistic sampling. No difference was observed between 2 years of sampling. The samples were stratified according to the proportional composition of the herds, defined at least as: four adult females, two adult males, and two lambs (6 months to 1 year old). We did not record if the lambs were twins.

Blood collection was performed in the sheep herd simultaneously with the application of two questionnaires: the first on farm data (region, source of drinking water, food facilities, land use (extensive/intensive), type of flooring, technical monitoring, presence of food trough, type of food trough, presence of water trough, type of water trough, presence of cats) and the second including information on age, sex, and breed of each sheep. Venous puncture of the 930 sheep was performed via a jugular vein and the serum was separated by centrifugation $(200 \mathrm{~g}$ for $5 \mathrm{~min}$ ) and stored at $-20{ }^{\circ} \mathrm{C}$ until use.

\section{ELISA and IgG avidity}

ELISA was carried out as described [7]. All the serum samples were tested in duplicate at a dilution of 1:400. Six negative sera and two positive sera, previously tested by IFAT and ELISA [7], were included as control. The cut-off value for each ELISA plate was calculated as the absorbance mean of six serum samples of sheep tested negative for $T$. gondii, plus three standard deviations tested on each plate. Avidity of IgG antibodies was calculated on previously positive samples as the ratio between the mean absorbance for each serum urea-treated (AU) divided by the absorbance mean of the untreated sera (A) expressed in percentage: AU/A $\times 100$ [8]. Avidity values $\geq 50 \%$ indicate chronic toxoplasmosis, while values $<50 \%$ suggest recent infection [28].

\section{Statistical analysis}

A database was generated using EpiData version 2.1 software and statistical analyses were performed using the Stata Statistical software version 10 SE. Seroprevalence for T. gondii and low- and high-avidity IgG antibodies were correlated with age, breed, and regions using the chi-square test. Univariate analysis was used to quantify the association between risk factors and infection by $T$. gondii, using logistic regression. The association measure used was the odds ratio (OR) and confidence interval (CI 95\%). Variables that presented $p<0.25$ in univariate analysis were applied in the multivariate logistic analysis. The $p$-value $<0.05$ was considered to build the final model, using the likelihood ratio test to define the model that would best fit the data.

\section{Results}

\section{Prevalence of toxoplasmosis in sheep}

Of the 930 sheep evaluated, 466 (50.1\%) were from the Central Potiguar region and 464 (49.9\%) from the Leste Potiguar region. Anti-T. gondii antibodies were detected in 205 animals $(22.1 \%$; CI 95\% = 19.5-24.8). We identified 122 (26.3\%; CI $95 \%=22.4-30.4)$ and 83 positive sheep $(17.8 \%$; CI $95 \%=14.5-21.5)$ in the Leste Potiguar and Central Potiguar regions, respectively $(p=0.002)$.

Table 1 shows seropositivity according to gender, age, and breed. The percentage of $22.1 \%$ of positive males (4 lambs and 24 adults) was similar to those observed for the females (25 lambs and 152 adults), $22.0 \%(p=0.999)$. Among the lambs, $12.8 \%$ were positive for toxoplasmosis, while adults showed seroreactivity of $25.0 \%$. These results show a positive association between the presence of anti- $T$. gondii antibodies and age of sheep $(p<0.001)$. Regarding breed, $22.6 \%$ of pure breed, $21.1 \%$ of crossbreed, and $19.4 \%$ of undetermined breed were positive $(p=0.705)$.

\section{IgG avidity}

Of the 205 seropositive sheep, 168 (81.9\%) had high-avidity IgG antibodies and 37 (18.1\%), low-avidity antibodies. No statistically significant difference $(p>0.05)$ was found between the frequency of low-avidity antibodies and breed or region. The avidity rates available by age showed significant differences $(p<0.05)$. The frequency of lambs presenting 
Table 1. Variables associated with seroprevalence of T. gondii infection in sheep, Rio Grande do Norte, Brazil.

\begin{tabular}{lcccc}
\hline Variables & & Examined & Positive (\%; CI 95\%) & $p$-value \\
\hline Gender & Males & 127 & $28(22.1 ; 15.7-30.0)$ & 0.999 \\
& Females & 803 & $177(22.0 ; 19.3-25.0)$ & $<0.001$ \\
Age & Lambs & 226 & $29(12.8 ; 9.1-17.8)$ & $176(25.0 ; 21.9-28.3)$ \\
& Adults & 704 & $165(22.6 ; 19.7-25.8)$ & 0.705 \\
Breed & Crossbreed & 730 & $16(21.1 ; 13.4-31.5)$ & \\
& Pure & 76 & $24(19.4 ; 13.4-27.2)$ & \\
Total & Undetermined & 124 & $205(22.1 ; 19.5-24.8)$ \\
\hline
\end{tabular}

low-avidity antibodies (37.9\%) was higher than that of adult animals $(14.8 \%)(p=0.004)$.

\section{Risk factors}

Variables associated with $T$. gondii infection in univariate analysis were: source of drinking water (running water or still water); type of flooring (dirt or cemented floor); location of drinking trough (animals drink inside the facilities or directly from water source); type of water trough (cement or plastic); type of food trough (cement or wood); presence of cats; food-storage facility, and age. The variables remaining in the final model were: presence of cats, sheep age (adult animals), and use of unexposed water obtained from deep well (Table 2). The presence of cats on the farms increased the chances of sheep to become infected with $T$. gondii $(\mathrm{OR}=1.55, \mathrm{CI}$ $95 \%=1.11-2.16)$. Adult sheep had a higher risk of infection when compared to lambs (OR $=2.44$; CI 95\% $=1.58-3.75)$. Sheep from farms where the water offered was obtained from running water systems sources had a higher risk to become infected with $T$. gondii than those from farms with still-water sources $(\mathrm{OR}=1.61$; CI 95\% $=1.25-2.09)$.

\section{Discussion}

Seroprevalence of anti- $T$. gondii antibodies observed in sheep from the state of Rio Grande do Norte was $22.1 \%$. This value is close to those previously observed in the same state, $29.4 \%$ and $20.7 \%$ of the sheep tested positive in the municipalities of Lajes and Mossoro, respectively [7, 27]. This value is also similar to those found in Italy $-28.5 \%$ [11], Finland - 24.6\% [15], Netherlands - 27.8\% [21], and China $29.8 \%$ [17]. However, it was higher than that found in Nigeria (6.7\%) [16]. In contrast, our data were lower than those observed in the Czech Republic - 59\% [3] and in India $44.1 \%$ [6]. The differences observed between these rates of prevalence may be related to the serological methods used in these studies (it should be taken into account that the different tests used to obtain these data are not standardized), system of exploitation, presence of definitive hosts, and climatic variables.

Among the regions studied in Rio Grande do Norte, seroprevalence varied from $17.8 \%$ in the Central Potiguar region to $26.3 \%$ in the Leste Potiguar region. These results show that
Table 2. Risk factors associated with toxoplasmosis in sheep, Rio Grande do Norte, Brazil.

\begin{tabular}{lccc}
\hline Risk factors & OR & CI 95\% & $p$ \\
\hline Water source & & & \\
Still water & 1 & - & - \\
Running water & 1.61 & $1.25-2.09$ & 0.000 \\
Presence of cats & & & \\
No & 1 & - & - \\
Yes & 1.55 & $1.11-2.16$ & 0.009 \\
Age & & & \\
Lambs & 1 & - & - \\
Adults & 2.44 & $1.58-3.75$ & 0.000 \\
\hline
\end{tabular}

climatic differences may influence on the spread of toxoplasmosis in sheep, considering that the Leste Potiguar region presents more favorable climatic conditions to the development and maintenance of $T$. gondii oocysts in the environment. Oocysts can survive in the environment for months, depending on moisture and temperature [30]. Thus, low humidity and high temperatures, typical of the Central Potiguar region, are deleterious to oocysts. This fact was also demonstrated in the state of Bahia, Brazil [24], where a prevalence of $12.5 \%$ was observed in the "caatinga" arid region and $26.92 \%$ in the humid area bordering the Atlantic Coast. This fact suggests that climate characteristics of dry regions are likely to decrease the chance of oocyst survival, generally resulting in a low prevalence of toxoplasmosis.

Our results show a positive association between age and seroprevalence. Adults animals showed higher seroreactivity than lambs. This is likely due to increasing opportunities of exposure to the infectious agent $[12,13]$. No relationship was found between sheep gender and seropositivity for toxoplasmosis, confirming previous studies [4, 5, 27]. No significant difference was found among breed categories analyzed. These data corroborate previous results $[25,31]$. However, in the state of Pernambuco, Brazil, it was observed higher prevalence in crossbred sheep [26]. Probably, this fact is due to the poor hygienicsanitary management adopted in the farms where crossbred sheep are raised. Our results show that less than $20 \%$ of the seropositive sheep have low-avidity anti-T. gondii IgG antibodies, suggesting recently acquired toxoplasmosis. Lambs have low-avidity antibodies with greater frequency. 
The risk factors identified for sheep toxoplasmosis in the regions studied in the state of Rio Grande do Norte were: age, presence of cats, and use of running water. Adult sheep are 2.44 times more likely $(\mathrm{CI} 95 \%=1.58-3.75)$ to be infected, compared to the younger animals. As noted earlier, older animals present a higher prevalence due to the increased contact time with oocysts of $T$. gondii in the environment [16, 23]. The presence of cats on the farms increased 1.55 (CI $95 \%=1.11-2.16)$ the risk for sheep to become infected with $T$. gondii. This association is likely due to a greater environmental contamination with oocysts eliminated in the feces of these felids $[1,18]$. Sheep reared on farms where drinking water was obtained from a running source (continuous replacement of water, obtained from a subterraneous source) had a 1.61 greater risk $(\mathrm{CI} 95 \%=1.25-2.09)$ to acquire toxoplasmosis than the animals from properties with still-water sources (partially stagnant water, without continuous replacement). This finding is corroborated by Pinheiro et al. [23] who observed that running water is a risk factor for toxoplasmosis. However, our results are discordant from those observed in southeastern Brazil [19]. These authors demonstrated that sheep from flocks using lake water are 1.67 times more likely to be infected compared to animal that drink spring water. Our results are different from expected, but we do not know the reasons. Due to a higher chance of exposure to cat feces, still water would be more likely to be contaminated with oocysts of $T$. gondii than running water. Anyway, drinking water must also be considered as an important means of agent transmission, acting as a disseminator of oocysts in flocks of sheep.

Based on the results of this study, it was concluded that T. gondii infection is common in Brazilian sheep from the state of Rio Grande do Norte. Age of the animals, presence of cats, and the use of unexposed source of water are risk factors for toxoplasmosis in sheep.

Acknowledgements. We thank Rosalida Estevan Nazar Lopes and Edson Santana for technical assistance. RWAV, MC, and VFAN are CNPq Research Fellows. MMCA is a CAPES scholar fellowship. The authors declare that there are no conflicts of interest.

\section{References}

1. Abu-Dalbouh MA, Ababneh MM, Giadinis ND, Lafi SQ. 2012. Ovine and caprine toxoplasmosis (Toxoplasma gondii) in aborted animals in Jordanian goat and sheep flocks. Tropical Animal Health and Production, 44, 49-54.

2. Barbosa IR, Holanda CMCX, Andrade-Neto VF. 2009. Toxoplasmosis screening and risk factors amongst pregnant females in Natal, northeastern Brazil. Transactions of the Royal Society of Tropical Medicine and Hygiene, 103, 377-382.

3. Bártová E, Sedlák K, Literák I. 2009. Toxoplasma gondii and Neospora caninum antibodies in sheep the Czech Republic. Veterinary Parasitology, 161, 131-132.

4. Caballero-Ortega H, Palma JM, García-Márquez LJ, GildoCárdenas A, Correa D. 2008. Frequency and risk factors for toxoplasmosis in ovines of various regions of the State of Colima, Mexico. Parasitology, 135, 1385-1389.

5. Carneiro ACAV, Carneiro M, Gouveia AMG, Vilas-Boas LS, Vitor RWA. 2009. Seroprevalence and risk factors of sheep toxoplasmosis in Minas Gerais, Brazil. Revue de Médecine Vétérinaire, 160, 527-531.

6. Chikweto A, Kumthekar S, Tiwari K, Nyack B, Deokar MS, Stratton G, Macpherson CNL, Sharma RN, Dubey JP. 2011. Seroprevalence of Toxoplasma gondii in pigs, sheep, goats, and cattle from Grenada and Carriacou, West Indies. Journal of Parasitology, 97, 950-951.

7. Clementino MM, Souza MF, Andrade Neto VF. 2007. Seroprevalence and Toxoplasma gondii-IgG avidity in sheep from Lajes, Brazil. Veterinary Parasitology, 146, 199-203.

8. Cozon GJN, Ferrandiz J, Nebhi H, Wallon M, Peyron F. 1998. Estimation of the avidity of immunoglobulin $G$ for routine diagnosis of chronic Toxoplasma gondii infection in pregnant women. European Journal of Clinical Microbiology \& Infectious Diseases, 17, 32-36.

9. Dubey JP, Lago EG, Gennari SM, Su C, Jones JL. 2012. Toxoplasmosis in humans and animals in Brazil: High prevalence, high burden of disease, and epidemiology. Parasitology, $10,1-50$.

10. Fayer R. 1981. Toxoplasmosis update and public health implications. Canadian Veterinary Journal, 22, 344-352.

11. Fusco G, Rinaldi L, Guarino A, Proroga YTR, Pesce A, Giuseppina M, Cringoli G. 2007. Toxoplasma gondii in sheep from the Campania region (Italy). Veterinary Parasitology, 149, 271-274.

12. Gorman T, Arancibia JP, Lorca M, Hird D, Alcaíno H. 1999. Seroprevalence of Toxoplasma gondii infection in sheep and alcapacas (Llama pacas) in Chile. Preventive Veterinary Medicine, 40, 143-149.

13. Halos L, Thébault A, Aubert D, Thomas M, Perret C, Geers R, Alliot A, Escotte-Binet S, Ajzenberg D, Dardé ML, Durand B, Boireau P, Villena I. 2010. An innovative survey underlining the significant level of contamination by Toxoplasma gondii of ovine meat consumed in France. International Journal for Parasitology, 40, 193-200.

14. Idema, Instituto de Desenvolvimento Sustentável e Meio Ambiente do RN. Anuário Estatístico 2010. Available on December 22, 2012, according IDEMA website at: http://www.idema.rn.gov.br/ contentproducao/aplicacao/idema/socio_economicos/arquivos/ Anuario-CDROM\%202010/index.htm.

15. Jokelainen $P$, Nareaho A, Knaapi S, Oksanen A, Rikula U, Sukura A. 2010. Toxoplasma gondii in wild cervids and sheep in Finland: North-south gradient in seroprevalence. Veterinary Parasitology, 171, 331-336.

16. Kamani J, Mani AU, Egwu GO. 2010. Seroprevalence of Toxoplasma gondii infection in domestic sheep and goats in Borno state, Nigeria. Tropical Animal Health and Production, 42, 793-797.

17. Liu Q, Ma R, Zhao Q, Shang L, Cai J, Wang X, Li J, Hu G, Jin H, Gao H. 2010. Seroprevalence of Toxoplasma gondii infection in Tibetan Sheep in Northwestern China. Journal of Parasitology, 96, 1222-1223.

18. Lopes WDZ, Santos TR, Silva RS, Rossanese WM, Souza FA, Rodrigues JDF, Mendonça RP, Soares VE, Costa AJ. 2010. Seroprevalence of and risk factors for Toxoplasma gondii in sheep raised in the Jaboticabal microregion, São Paulo State, Brazil. Research in Veterinary Science, 88, 104-106.

19. Luciano DM, Menezes RC, Ferreira LC, Nicolau JL, Neves LB, Luciano RM, Dahrough MAA, Amendoeira MR. 2011. Soroepidemiologia da toxoplasmose em caprinos e ovinos de três municípios do Estado do Rio de Janeiro. Pesquisa Veterinaria Brasileira, 31, 569-574. 
20. Moraes EPBX, Costa MM, Dantas AFM, Silva JCR, Mota RA. 2011. Toxoplasma gondii diagnosis in ovine aborted fetuses and stillborns in the State of Pernambuco, Brazil. Veterinary Parasitology, 183, 152-155.

21. Opsteegh M, Teunis P, Mensink M, Züchner L, Titilincu A, Langelaar M, Giessen JV. 2010. Evaluation of ELISA test characteristics and estimation of Toxoplasma gondii seroprevalence in Dutch sheep using mixture models. Preventive Veterinary Medicine, 96, 232-240.

22. Panadero R, Painceira A, López C, Vázquez L, Paz A, Díaz P, Dacal V, Cienfuegos S, Fernández G, Lago N, Díez-Baños P, Morrondo P. 2010. Seroprevalence of Toxoplasma gondii and Neospora caninum in wild and domestic ruminants sharing pastures in Galicia (Northwest Spain). Research in Veterinary Science, 88, 111-115.

23. Pinheiro JW Jr, Mota RA, Oliveira AAF, Faria EB, Gondim LFP, Silva AV, Anderlini GA. 2009. Prevalence and risk factors associated to infection by Toxoplasma gondii in ovine in the State of Alagoas, Brazil. Parasitology Research, 105, 709-715.

24. Pita Gondim LF, Barbosa HV Jr, Ribeiro Filho CHA, Saeki H. 1999. Serological survey of antibodies to Toxoplasma gondii in goats, sheep, cattle and water buffaloes in Bahia State Brazil. Veterinary Parasitology, 82, 273-276.

25. Ragozo AMA, Yai LEO, Oliveira LN, Dias RA, Dubey JP, Gennari SM. 2008. Seroprevalence and isolation of Toxoplasma gondii from sheep from São Paulo State, Brazil. Journal of Parasitology, 94, 1259-1263.

26. Silva AV, Cunha ELP, Meireles LR, Gottschalk S, Mota RA, Langoni H. 2003. Sheep and goat toxoplasmosis: soroepidemiological study in two regions in the state of Pernambuco, Brazil. Ciência Rural, 33, 115-119.

27. Soares HS, Ahid SMM, Bezerra ACDS, Pena HFJ, Dias RA, Gennari SM. 2009. Prevalence of anti-Toxoplasma gondii and Neospora caninum antibodies in sheep from Mossoró, Rio Grande do Norte, Brazil. Veterinary Parasitology, 160, 211-214.

28. Suaréz-Aranda F, Galisteo AJ Jr, Hiramoto RM, Cardoso RPA, Meireles LR, Miguel O, Andrade HF Jr. 2000. The prevalence and avidity of Toxoplasma gondii IgG antibodies in pigs from Brazil and Peru. Veterinary Parasitology, 91, 23-32.

29. Sukthana Y. 2006. Toxoplasmosis: beyond animals to humans. Trends in Parasitology, 22, 137-142.

30. Tenter AM, Heckeroth AR, Weiss LM. 2000. Toxoplasma gondii: from animals to humans. International Journal for Parasitology, 30, 1217-1258.

31. Van der Puije WNA, Bosompem KM, Canacoo EA, Wastling JM, Akanmori BD. 2000. The prevalence of anti-Toxoplasma gondii antibodies in Ghanaian sheep and goats. Acta Tropica, $76,21-26$

Cite this article as: Andrade MMC, Carneiro M, Medeiros AD, Neto VA \& Vitor RWA: Seroprevalence and risk factors associated with ovine toxoplasmosis in Northeast Brazil. Parasite, 2013, 20, 20.

O PARASTE

An international open-access, peer-reviewed, online journal publishing high quality papers on all aspects of human and animal parasitology

Reviews, articles and short notes may be submitted. Fields include, but are not limited to: general, medical and veterinary parasitology; morphology, including ultrastructure; parasite systematics, including entomology, acarology, helminthology and protistology, and molecular analyses; molecular biology and biochemistry; immunology of parasitic diseases; host-parasite relationships; ecology and life history of parasites; epidemiology; therapeutics; new diagnostic tools.

All papers in Parasite are published in English. Manuscripts should have a broad interest and must not have been published or submitted elsewhere. No limit is imposed on the length of manuscripts.

Parasite (open-access) continues Parasite (print and online editions, 1994-2012) and Annales de Parasitologie Humaine et Comparée (1923-1993) and is the official journal of the Société Française de Parasitologie.
Submit your manuscript at http://parasite.edmgr.com/ 